\title{
Eyestalk ablation affects larval morphogenesis in the swimming crab Portunus trituberculatus during metamorphosis into megalopae
}

\author{
Shigeki Dan ${ }^{1}$, Takaaki Kaneko ${ }^{2}$, Satoshi Takeshima ${ }^{3}$, Masakazu Ashidate ${ }^{1}$, \\ Katsuyuki Hamasaki ${ }^{2, *}$ \\ ${ }^{1}$ Tamano Laboratory, National Research Institute of Fisheries and Environment of Inland Sea, Fisheries Research Agency, \\ Tamano, Okayama 706-0002, Japan \\ ${ }^{2}$ Graduate School of Marine Science and Technology, Tokyo University of Marine Science and Technology, Konan, Minato, \\ Tokyo 108-8477, Japan \\ ${ }^{3}$ Hakatajima Laboratory, National Research Institute of Fisheries and Environment of Inland Sea, Fisheries Research Agency, \\ Imabari, Ehime 794-2305, Japan
}

\begin{abstract}
To understand the role of the eyestalk neurosecretory system in regulation of larval morphogenesis, we performed eyestalk ablation on swimming crab Portunus trituberculatus larvae at various times during zoeal development. We measured the length of the chelae and pleopods, which become enlarged during development, and the dorsal spine and telson furcae, which are resorbed during metamorphosis in the final (fourth) stage zoeae and subsequent larval stages, including a supernumerary fifth stage zoeae and megalopae (fifth-instar larvae). The length of the chela and pleopod of fourth stage zoeae decreased when the bilateral eyestalks were ablated earlier during development. Eyestalk ablation had little effect on the zoeal dorsal spine and furcae. In fifth-instar larvae, the effects of eyestalk ablation changed radically depending on the time when the ablation was performed, and a critical period during the premoult of the third zoeal stage was identified. Ablation before this period caused retention of a large dorsal spine and furcae and resulted in moult to the supernumerary fifth zoeal stage. Ablation after this period allowed larvae to metamorphose into normal megalopae. Ablation during this period resulted in megalopae with immature morphology, whereby the larvae retained small dorsal spines and telson furcae. The results demonstrated that the eyestalk neurosecretory system most likely regulates larval morphogenesis during metamorphosis in 2 ways: the morphogenesis of body parts that are enlarged are continuously controlled throughout the zoeal stages, whereas the resorption of body parts is controlled instantaneously at a critical point during the premoult of the third zoeal stage.
\end{abstract}

KEY WORDS: Larval morphogenesis - Larval metamorphosis · Morphological abnormality · Mass mortality in seed production · Moult-death syndrome

\section{INTRODUCTION}

The larval development of brachyuran crabs is generally accompanied by metamorphosis during which individuals undergo a distinct morphological change

\footnotetext{
${ }^{*}$ Corresponding author: hamak@kaiyodai.ac.jp
}

from a planktonic zoea to a crab-like megalopa (Anger 2001a). Although larval metamorphosis is a major event in crab life history, little is known about the mechanisms regulating this metamorphosis. In contrast, the endocrine systems controlling the moulting

(C) The authors 2014. Open Access under Creative Commons by Attribution Licence. Use, distribution and reproduction are unrestricted. Authors and original publication must be credited. 
cycle and sexual maturity have been intensively studied in adult decapod crustaceans (Keller 1992, Hopkins 2012). Our understanding of crustacean endocrinology has largely been developed based on investigations into the role of the eyestalk (Hopkins 2012). The eyestalk consists, in part, of an X-organ and sinus gland, both of which are important parts of the neurosecretory system. In crab larvae, to our knowledge, only 3 studies have examined the effects of eyestalk ablation in zoeae on larval development in Sesarma reticulatum and Rhithropanopeus harrisii (Costlow 1966a,b, Freeman \& Costlow 1980). These studies demonstrated that bilateral eyestalk ablation of zoeae resulted in retardation or inhibition of metamorphosis into megalopae depending on the timing of ablation. Eyestalk ablation during early zoeal stages resulted in the occurrence of a supernumerary additional zoeal stage. Larval eyestalk ablation of snapping shrimp Alpheus heterochaelis, American lobster Homarus americanus, and shrimp Palaemon macrodactylus also resulted in delayed or inhibited metamorphosis when ablation occurred before a critical point in the zoeal stage (Little 1969, Snyder \& Chang 1986, Charmantier \& Aiken 1987, Charmantier et al. 1988, Knowlton 1994, Gross \& Knowlton 1997, 1999, 2002). Moreover, some of these studies noted that eyestalk ablation induced the development of morphologically distinct megalopae (postlarvae) that were characterised as larval-postlarval intermediates because they exhibited both zoeal and megalopal features of the carapace (shape), appendages and telson. For example, $R$. harrisii megalopae retained a small dorsal spine on the carapace and $H$. americanus postlarvae retained long lateral spines on the telson (Costlow 1966a, Charmantier \& Aiken 1987, Knowlton 1994, Gross \& Knowlton 2002). Taken together, these observations suggest that the larval metamorphosis of decapod crustaceans is regulated by the neurosecretory system located in the eyestalks.

In recent years, the large-scale larval culture of commercially important brachyuran crabs has expanded globally because of the increase in demand for crab seed for purposes of aquaculture and stock enhancement (Keenan \& Blackshaw 1999, Davis et al. 2005, Wang et al. 2005, Zmora et al. 2005, Kogane et al. 2007, Castine et al. 2008, Cheng et al. 2008, Hamasaki \& Kitada 2008, Hamasaki et al. 2011, Jinbo et al. 2013). Accordingly, there has been an increase in the number of rearing trials to improve larval rearing techniques. As a result, there has been a concomitant increase in the number of reports documenting the existence of variations in larval morphology and a relationship with larval mass mortality during seed production (Hamasaki et al. 2002a,b, 2011, Arai et al. 2004, Takano et al. 2004, Dan \& Hamasaki 2011, Silva et al. 2012, Dan et al. 2013). Arai et al. (2004) reported that, during seed production of the swimming crab Portunus trituberculatus, morphologically advanced fourth stage (last stage) zoeae failed to shed their exuviae completely during their metamorphosis into megalopae and eventually died. These final stage zoeae had morphological features similar to megalopae, such as large chelipeds and long pleopods with natatory setae. This mortality phenomenon is known as 'moult-death syndrome' (Mann et al. 1999), and it has also been documented in other brachyuran crabs such as Scylla paramamosain, Scylla serrata, and Ucides cordatus (Mann et al. 1999, Hamasaki et al. 2002a,b, Takano et al. 2004, Dan \& Hamasaki 2011, Silva et al. 2012). Furthermore, our previous study demonstrated that there were significant variations in the morphology of Portunus trituberculatus megalopae cultured in 12 hatcheries in Japan. In this instance, the occurrence of morphologically immature megalopae that retained zoeal morphological features, such as a small dorsal spine and telson furcae, was related to larval mass mortality in this species (Dan et al. 2013). Such immature morphology of megalopae has also been reported in other brachyuran crab species such as Aratus pisonii, Paramola petterdi, Pinnaxodes mutuensis, and Pinnotheres pisum under artificial rearing conditions (Atkins 1955, Williamson 1965, Warner 1968, Konishi 1981). These observations suggest that morphological variations in final stage zoeae and megalopae are relatively common among crab species, and abnormality in morphogenesis has been a bottleneck limiting the hatchery production of commercially important brachyuran crabs.

To determine the cause of abnormal morphogenesis in brachyuran crab larvae, there is a need to improve our knowledge of the control mechanisms for larval morphogenesis, in particular the regulation of metamorphosis into megalopae by the eyestalk neurosecretory system. Therefore, we conducted eyestalk ablation on $P$. trituberculatus larvae at various times during zoeal development. To quantify the effects of treatment on larval morphogenesis, we measured the dimensions of larval body parts that are enlarged during metamorphosis (e.g. the chelae and pleopods; megalopal features) and those that are resorbed during metamorphosis (e.g. dorsal spine and telson furcae; zoeal features). Our results provide new insights into the causes of abnormal morphogenesis of brachyuran crab larvae under artificial rearing conditions. 


\section{MATERIALS AND METHODS}

\section{Broodstock and larvae}

A total of 12 ovigerous female Portunus trituberculatus were captured by small beam-trawls between July 24 and 25, 2011 in the Seto Inland Sea off Asakuchi, Okayama, Japan. They were transferred to the Tamano laboratory of the National Research Institute of Fisheries and Environment of Inland Sea, Fisheries Research Agency, Tamano, Okayama, Japan, on July 25 at 11:00 h, and stocked in separate cages in a $1.7 \mathrm{kl}$ fibreglass-reinforced plastic (FRP) tank. Sand-filtered and ultraviolet-irradiated seawater was supplied to the tank with a flow-through water system. Three females (carapace width: 179, 206 and $210 \mathrm{~mm}$ ) carrying eggs which could be predicted to hatch within a day were selected by microscopic observation of egg subsamples according to Hamasaki et al. (2003). At 16:00 h, each female was transferred to a cylindrical $600 \mathrm{l}$ FRP tank containing still seawater sterilised with chlorine (5 ppm) and neutralised with sodium thiosulfate. The water temperature was maintained at $25^{\circ} \mathrm{C}$, and aeration was provided via an air stone. As expected, these females hatched their eggs during the night, July 25 , and their larvae were used for the experiments outlined below beginning the next morning.

\section{Larval rearing in a 5001 tank}

A subsample of the first stage zoeae (Z1) that hatched from each female were transferred from the hatching tank to a $30 \mathrm{l}$ chamber, and the number of larvae was determined using a volumetric method based on three $50 \mathrm{ml}$ samples taken from the chamber after the water had been agitated to ensure a homogeneous distribution of the larvae. A mixture of equal numbers of $\mathrm{Z} 1$ larvae from each of the 3 females was stocked and reared in a cylindrical $500 \mathrm{l}$ polyethylene tank filled with sand-filtered seawater sterilised with chlorine (10 ppm) and neutralised with sodium thiosulfate prior to larval stocking. The stocking density of Z1 was 8000 ind. per 500 l. Sodium nifurstyrenate $\left(2 \mathrm{mg} \mathrm{l}^{-1}\right.$, Ueno Fine Chemicals Industry) was added at the beginning of the larval rearing period to prevent bacterial infection. The seawater in the rearing tanks was not renewed during the larval culture period. The salinity of the rearing water was $33 \mathrm{ppt}$ at the beginning and the end of the larval rearing. Gentle aeration was provided via an air stone. The photoperiod mimicked natural conditions: $14 \mathrm{~h}$ light (05:00 to 19:00 $\mathrm{h}$ ) and $10 \mathrm{~h}$ dark. The mean $\pm \mathrm{SD}$ light intensity at 13:00 h was $8477 \pm 6710 \mathrm{~lx}$. The water temperature was maintained by an air conditioner in the room in which the tank was placed. The mean \pm SD values for water temperature, dissolved oxygen, and $\mathrm{pH}$ measured once a day during the rearing period were $25.6 \pm 0.1^{\circ} \mathrm{C}, 8.00 \pm 0.34 \mathrm{mg} \mathrm{l}^{-1}$ and $8.06 \pm 0.16$, respectively.

The rearing tank was supplemented once on the day of stocking with rotifer Brachionus plicatilis species complex (25 ind. $\mathrm{ml}^{-1}$ ) that was cultured with commercially available concentrated phytoplankton Nannochloropsis sp. (Yanmarine K-1, Chlorella Industry). To maintain the rotifer population in the larval rearing tank, Nannochloropsis sp. was added to the tank twice a day to maintain a density of 200000 cells $\mathrm{ml}^{-1}$ throughout the rearing period. Artemia cysts (Utah Strain, Kitamura) were hatched daily for $24 \mathrm{~h}$ at $26^{\circ} \mathrm{C}$, and newly hatched nauplii were added to the tank once each morning to maintain densities of 0.5 and 1.0 ind. $\mathrm{ml}^{-1}$ for the third stage zoeae (Z3) and fourth stage zoeae (Z4), respectively. Every day, 20 larvae were sampled from the tank and observed using a stereo microscope. The larval moulting stage and the developmental stage within the moulting cycle was determined according to the criteria as described by Anger (2001b).

\section{Larval treatment}

P. trituberculatus have 4 zoeal stages (Z1 to Z4) and the stalked eyes begin to develop when larvae moult to the second zoeal stage (Z2). Therefore, eyestalk ablation was performed on Z2 to Z4 larvae. The larvae were collected from the $500 \mathrm{ltank}$, and the bilateral eyestalks were ablated using 2 thin needles with handles under a stereo microscope. Simultaneously, the larval moulting stage and the developmental stage within the moulting cycle were verified. The eyestalk-ablated larvae were stocked in $1 \mathrm{l}$ plastic beakers, then reared until the Z4 larvae had moulted to the next stage, which is termed the fifth-instar stage in this study. To test the potential effects of physical damage associated with eyestalk ablation, a comparative treatment was included in which twothirds of the dorsal spines of larvae were ablated using the same operating technique as with eyestalk ablation. Additionally, to control for the effects of loss of vision in the eyestalk-ablated individuals, a group of intact larvae were reared in 11 beakers in complete darkness (0 lx: darkness control). Lastly, a control group (handling) consisting of intact larvae that 
were transferred from the 5001 tank to 11 beakers was also prepared. All treatments were conducted on the first day of the Z2 (2 d after hatching [dah]), Z3 (4 dah), and Z4 (6 dah) stages. These larvae were classified as being in the postmoult period (Stage B, in sensu Anger 2001b). To evaluate the effect of timing of eyestalk ablation within the moulting cycle across the entire zoeal period on larval morphogenesis, eyestalk ablation was also conducted in the premoult period (Stage D1 to D2) of Z2 (3 dah) and Z3 (5 dah) larvae, and in the intermoult period (Stage C, $7 \mathrm{dah}$ ) and the premoult period (Stage D2 to D3, 8 dah) of Z4 larvae.

\section{Larval rearing in 11 beakers}

A total of 25 larvae were stocked in each 11 beaker and larval rearing was conducted in quadruplicate for each treatment group. The beakers containing the control, dorsal spine ablation, and eyestalk ablation treatment groups were placed in shallow water baths, and the temperature was maintained at $25.6 \pm$ $0.4^{\circ} \mathrm{C}$ (mean $\pm \mathrm{SD}$ ) by a heater connected to a thermostat. The water temperature of the darkness control was maintained at $25.5^{\circ} \mathrm{C}$ using an incubator. The beakers were lightly aerated to provide oxygen and sufficient turbulence to prevent the rotifers and Artemia from settling. All the beakers except for those of the darkness control were located in the laboratory where the $500 \mathrm{l}$ tank was placed. Thus, the photoperiod was the same as that described for the 5001 tank. Each morning, larvae were transferred with a large-mouthed pipette to newly prepared beakers containing freshly sterilised seawater and food. To prevent bacterial proliferation, dihydrostreptomycin sulphate $\left(50 \mathrm{mg} \mathrm{l}^{-1}\right.$, Tamura Seiyaku) was added to the seawater. The rotifers cultured with Nannochloropsis sp. were fed to the larvae at a density of 50 ind. $\mathrm{ml}^{-1}$ throughout the zoeal stages. Newly hatched Artemia nauplii were also provided to the larvae at densities of 0.5 and 1.0 ind. $\mathrm{ml}^{-1}$ during the $\mathrm{Z} 3$ and Z4 stages, respectively. The number of live and dead larvae and the larval moulting stage were determined daily. As the concentration of the Artemia supplementation varied among the moult stages, the individuals at differ- ent moult stages within a group/replicate were reared in separate beakers.

For morphological measurements, 5 recently moulted Z4 larvae and all fifth-instar larvae were sampled from each replicate group, fixed with $10 \%$ neutral formalin for $24 \mathrm{~h}$ and then preserved in a $70 \%$ ethanol solution.

\section{Morphological measurements}

We selected the morphological traits which indicate the significant changes related to metamorphosis from zoeal to megalopal stages during normal morphogenesis, e.g. enlargement of chelae and pleopods, and resorption of a dorsal spine and telson furcae (Table 1). Therefore, we measured the length of chela (CHL) and the third pleopod (PL) in Z4, and the CHL in fifth-instar larvae using a microscope (Fig. 1a,b). These values were used as indices of morphological enlargement during the metamorphosis into megalopae (MG) (Table 1). Additionally, we measured dorsal spine length (DSL) and total length of the bilateral telson furcae (FL) in Z4 and fifthinstar larvae (Fig. 1C,f). These values were used as indices of morphological resorption during metamorphosis into MG. To exclude the effect of differences in somatic growth among treatments, the ratios of CHL, PL, DSL and FL to the carapace length (CL) were also calculated and are reported as CHLr, PLr,

Table 1. Abbreviations used to represent the morphological measurements taken from fourth stage zoeae and fifth-instar larvae (supernumerary fifth stage zoeae and megalopae) of the swimming crab Portunus trituberculatus and their normal changes during metamorphosis into megalopae. See Fig. 1 for further details

\begin{tabular}{|llc|}
\hline Abbreviation & Morphological trait & $\begin{array}{c}\text { Changes during } \\
\text { metamorphosis }\end{array}$ \\
\hline CL & Carapace length $(\mu \mathrm{m})$ & \\
CHL & Chela length $(\mu \mathrm{m})$ & Increase \\
CHLr & Ratio of CHL to CL $(\%)$ & Increase \\
PL & Third pleopod length $(\mu \mathrm{m})$ & Increase \\
PLr & Ratio of PL to CL $(\%)$ & Increase \\
DSL & Dorsal spine length $(\mu \mathrm{m})$ & Resorbed \\
DSLr & Ratio of DSL to CL $(\%)$ & Recrease \\
FL & Sum of bilateral furcae length on & Decrease \\
& telson ( $\mu$ ) & Normally zero \\
FLr & Ratio of FL to CL $(\%)$ & Normally zero \\
DSf & Percentage of fifth-instar larvae that & \\
TELf & retain dorsal spines & Normally zero \\
Z5f & Percentage of fifth-instar larvae that & \\
& retain furcae on the telson & \\
\hline
\end{tabular}



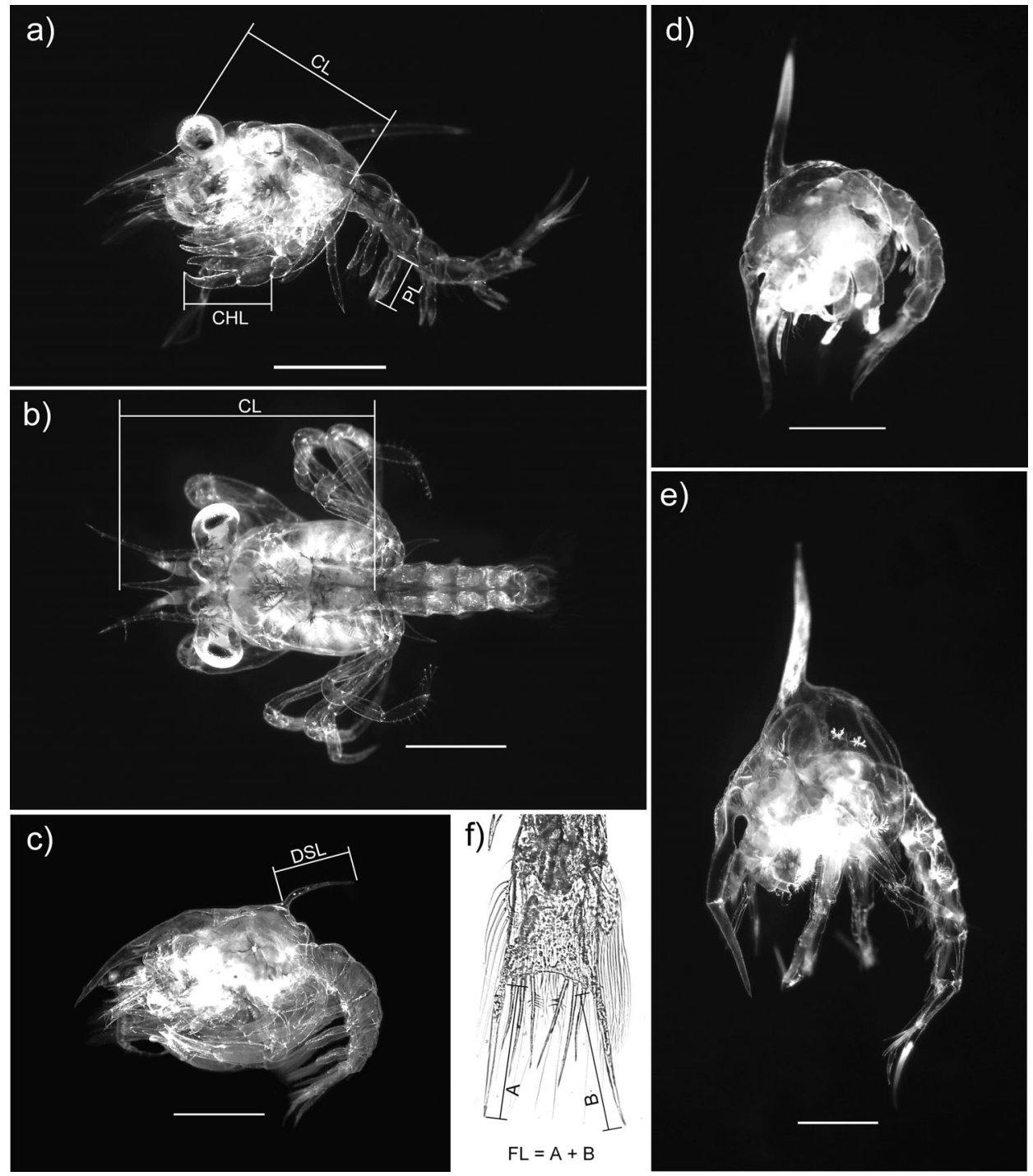

Fig. 1. Photographs of zoeae and megalopae of the swimming crab Portunus trituberculatus showing schematic diagrams of morphological measurements. (a) Fourth stage zoea; (b) megalopa; (c) morphologically immature megalopa induced by bilateral eyestalk ablation during premoult of the third zoeal stage; (d) supernumerary fifth stage zoea induced by bilateral eyestalk ablation during the postmoult of the second zoeal stage; (e) sixth stage zoea moulted from a supernumerary fifth stage zoea; (f) telson of megalopa retaining furcae. CL: carapace length; CHL: chela length; PL: pleopod length; DSL: dorsal spine length; FL: total furcae length. Scale bars $=1 \mathrm{~mm}$

DSLr and FLr, respectively. Because the dorsal spine and the telson furcae disappear completely in normal MG, the proportion (frequency) of fifth-instar larvae that retained the dorsal spines (DSf) and furcae on their telsons (TELf) was calculated and used as an index of incomplete metamorphosis. The morphological measurements for CHL, PL and DSL and the shape of telson are described in more detail by Dan et al. (2013). In some eyestalk ablation treatment replicates, some fifth-instar larvae exhibited morphological features typical of zoeae (e.g. laterally compressed carapace, long dorsal and rostrum spines, maxillipeds that function to aid swimming, non-functional chelipeds and walking legs, and forked telson) (Gore 1985) (Fig. 1d). We identified these larvae as a supernumerary zoeal stage (fifth stage zoeae, Z5) according to Costlow (1966a). We then calculated the frequency of $Z 5$ to the total number of fifth-instar larvae (Z5f). As the carapace shape of Z5 was completely identical to that of $\mathrm{Z} 4$ and individuals frequently lost or bent the tip of their long rostrum spine, the CL of $\mathrm{Z} 5$ was measured according to the method used for Z4 (Fig. 1a,d). The abbreviations used for the morphological measurements are provided in Table 1. 


\section{Data analysis}

Statistical analyses were performed using $\mathrm{R}(\mathrm{R}$ 3.0.2; R Development Core Team 2013) with a $5 \%$ significance level. To examine the effects of treatments (control, darkness, dorsal spine ablation and eyestalk ablation) on survival and developmental velocity of larvae treated at the postmoult stage in Z2, Z3 and Z4, we applied a generalised linear model (GLM) (McCullagh \& Nelder 1989, Everitt \& Hothorn 2009) with the glm function. To test for differences in survival, the cumulative numbers of live and dead animals to reach each larval moulting stage were used as the response variable with the quasi-binomial family (logit link), to account for the overdispersion of error distribution. To avoid the errors attributed to zero data in the analyses using the quasi-binomial family, the groups showing $100 \%$ survival were excluded from the analyses. In the analyses of larval developmental velocity, the number of days to reach each moulting stage by each larva was used as the response variable with the Poisson family (logarithmic link). In these analyses, the explanatory variable was treatment (control, darkness, dorsal spine ablation and eyestalk ablation). The statistical significance of the explanatory variables was evaluated with an $F$-test (quasi-binomial family) or the Wald $\chi^{2}$ test (Poisson family) using the Anova function (Type II) implemented in the car package (Fox \& Weisberg 2011). Furthermore, differences between treatments were evaluated with the Tukey method using the glht function implemented in the multcomp package (Hothorn et al. 2008).

The effect of the treatments on morphology was also analysed using the GLM. The morphological measurements were used as response variables with the Gaussian family (identical link) (CL, CHL, CHLr, PL, PLr, DSL, DSLr, FL and FLr) or quasi-binomial family (logit link) (Z5f, DSf and TELf), to account for the overdispersion of error distribution. In these analyses, the explanatory variables were larval age and the categorical fixed factors (treatments). Because the dorsal spine and telson furcae were absent in almost all fifthinstar larvae from the control, darkness, and dorsal spine ablation treatments, the DSL and FL values were very low (they moulted to normal megalopae). Thus, we did not compare the DSLr and FLr of the fifth-instar larvae among treatments. Furthermore, data for the CL and CHLr of Z5 from the eyestalk ablation treatment were not included in the analyses for the fifth-instar larvae, because the method of measuring CL differed between Z5 and MG (Fig. 1).The significance of the explanatory variables was evaluated with an F-test and differences between treatments were tested using the glht function.

To evaluate the effects of timing of eyestalk ablation at various points in the moulting cycle throughout the entire zoeal period on morphogenesis, larval age was used as the explanatory variable in the GLM. In this analysis, morphological measurements were used as response variables and the significance of the explanatory variable was evaluated using an F-test. As the method of measuring CL differed between Z5 and MG in the fifth-instar larvae (Fig. 1), the data for CL, CHLr, PLr, DSLr and FLr from Z5 and MG were analysed separately.

\section{RESULTS}

\section{Larval survival}

The larvae developed successfully through their fifth-instar stages in all treatments tested (Fig. 2). When eyestalks were ablated at the Z2-postmoult stage, the treatments had a significant effect on survival to all moulting stages (to reach Z3, $F=10.87, \mathrm{df}=$ $3,12, \mathrm{p}=0.0010$; to reach $\mathrm{Z} 4, F=10.92, \mathrm{df}=3,12, \mathrm{p}=$ 0.0010 ; to reach fifth-instar stage, $F=8.103, \mathrm{df}=3,12$, $\mathrm{p}=0.0032$ ), and survival to the fifth-instar stage was significantly lower in the eyestalk ablation group (8.8 \pm 2.1 ind.; mean $\pm \mathrm{SD}$ ) than in other treatment groups (control, $14.0 \pm 0.0$ ind.; darkness, $11.8 \pm 1.3$ ind.; dorsal spine ablation, $11.5 \pm 1.7$ ind.) (Fig. 2a). When eyestalks were ablated at the Z3-postmoult stage, the treatments also had a significant effect on survival to all moulting stages (to reach $\mathrm{Z} 4, F=31.71$, df $=3,12$, $\mathrm{p}<0.0001$; to reach fifth-instar stage, $F=11.52, \mathrm{df}=3$, $12, \mathrm{p}=0.0008$ ), and survival to the fifth-instar stage was again significantly lower in the eyestalk ablation group (10.5 \pm 3.8 ind.) than in other treatment groups (control, $19.0 \pm 1.2$ ind.; darkness, $17.5 \pm 1.9$ ind.; dorsal spine ablation, $17.3 \pm 0.5$ ind.) (Fig. $2 b$ ). When eyestalks were ablated at the Z4-postmoult stage, treatment did not effect survival $(F=1.655$, df $=3,12, \mathrm{p}=$ 0.2292 ), and the mean number of surviving larvae in each treatment group ranged from 20.8 to 24.0 ind. (Fig. 2c). Overall, the highest and the lowest survival was in the control and eyestalk ablation groups, respectively. In the eyestalk ablation treatment groups, the mean number of surviving fifth-instar larvae following ablation treatment at the Z2-, Z3- and Z4-premoult, and Z4-intermoult stages ranged from 6.8 to 18.0 ind. (Fig. 2 d-f) and was similar to the range in the postmoult treatments (Fig. 2a-c). Thus, eyestalk ablation reduced larval survival. 
a) Z2-postmoult
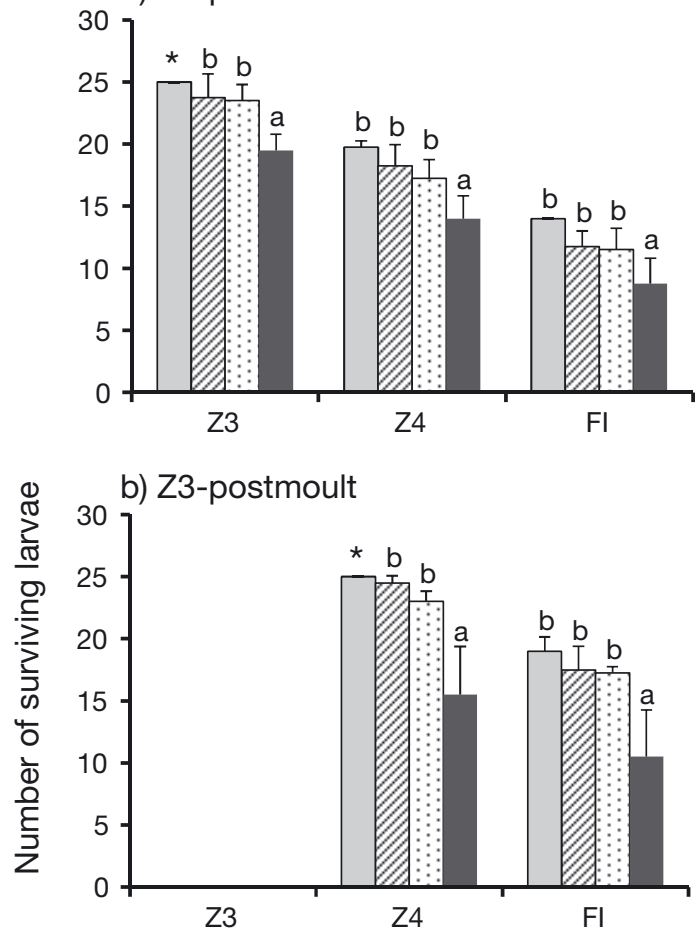

c) Z4-postmoult

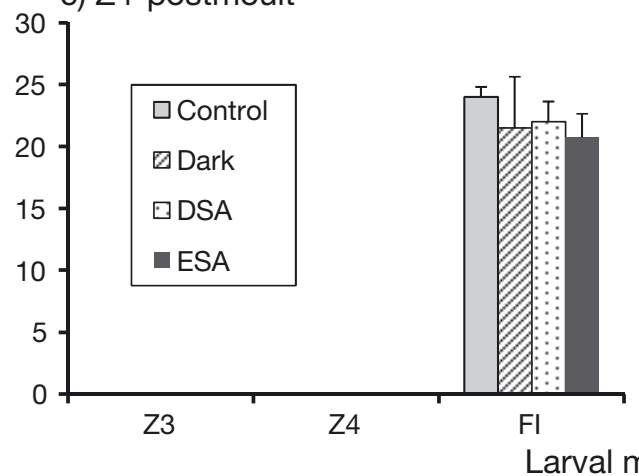

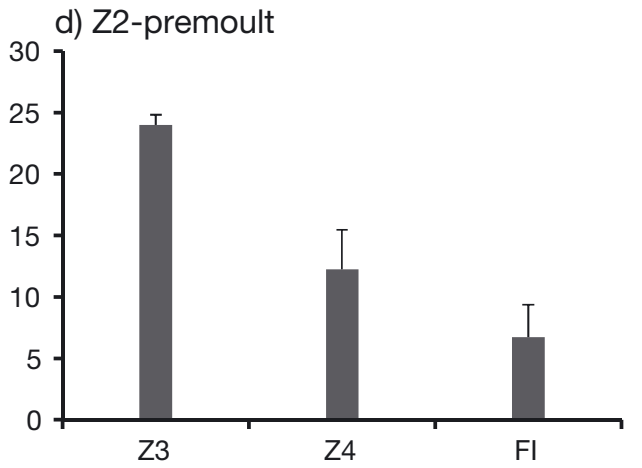

e) Z3-premoult

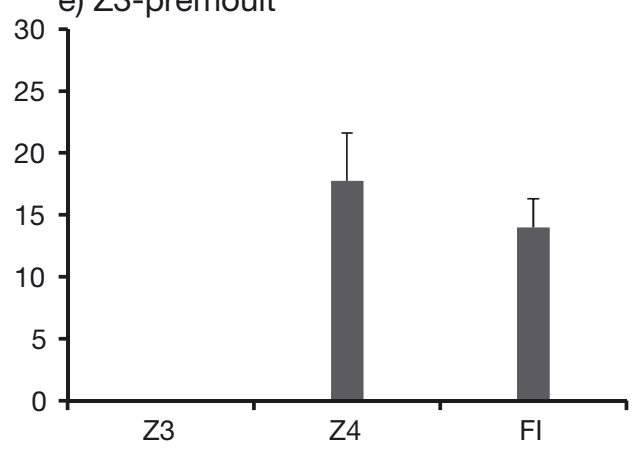

f) Z4-intermoult, premoult

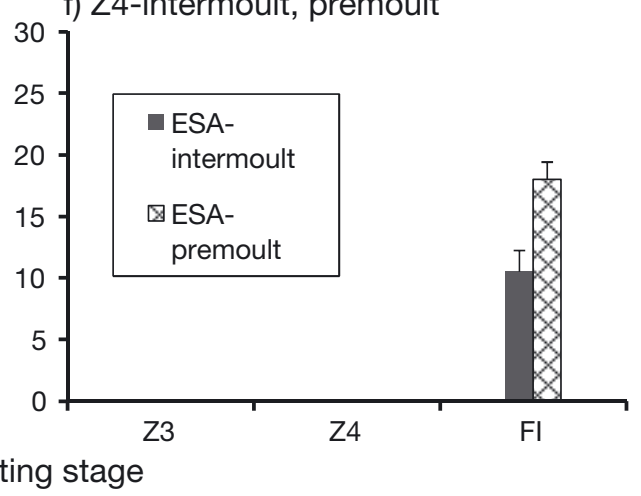

Fig. 2. Number of surviving Portunus trituberculatus larvae that reach each larval moulting stage following treatment during the postmoult of the (a) second (Z2), (b) third (Z3) or (c) fourth (Z4) zoeal stages, premoult of the (d) second or (e) third zoeal stages, or (f) intermoult or premoult of the fourth zoeal stage. Vertical bars indicate the SD of 4 replicates in each treatment group. Significant differences between the control (Control), darkness (Dark), dorsal spine ablation (DSA), and eyestalk ablation (ESA) treatment groups are indicated by a different letter $(p<0.05)$. FI: fifth instar stage including fifth zoeal and megalopal stages. Asterisks indicate the groups with $100 \%$ survival which were excluded from the analyses to avoid errors

\section{Larval developmental velocity}

When different treatments were conducted during the Z2-postmoult, they did not have a significant effect on the cumulative developmental time required to reach the $\mathrm{Z} 3$ stages $\left(\chi^{2}=6.563, \mathrm{df}=3, \mathrm{p}=0.0872\right)$, but did have significant effects on the time needed to reach the $\mathrm{Z} 4$ and fifth-instar stages (to reach $\mathrm{Z} 4, \chi^{2}=$ 8.753, $\mathrm{df}=3, \mathrm{p}=0.0328$; to reach fifth-instar stage, $\chi^{2}$ $=13.32, \mathrm{df}=3, \mathrm{p}=0.0040)$. The developmental time required to reach the fifth-instar stage was significantly shorter in the control and eyestalk ablation group (control; $10.6 \pm 0.14$ dah, eyestalk ablation; $10.5 \pm 0.60 \mathrm{dah})$ than in the darkness group $(12.8 \pm$ $0.26 \mathrm{dah}$ ), and there was no significant difference between the dorsal spine ablation group (11.4 \pm 0.23 dah) and other groups (Table 2). When treatments were carried out during the Z3-postmoult, they did not significantly affect developmental time (to reach Z4, $\chi^{2}=0.1042, \mathrm{df}=3, \mathrm{p}=0.9913$; to reach fifth-instar 
Table 2. Cumulative developmental time required to reach each moulting stage of Portunus trituberculatus larvae treated during the postmoult of the second (Z2), third (Z3), or fourth (Z4) zoeal stages, premoult of Z2 or Z3, or intermoult and premoult of Z4. Values are mean \pm SD. Significant differences were found between treatments with different superscripts in the same column within the same treatment (multiple comparisons with the Tukey method, $\mathrm{p}<0.05)$. dah: d after hatching, FI: fifth instar stage including fifth zoeal and megalopal stages

\begin{tabular}{|lcccc|}
\hline \multirow{2}{*}{ Time at treatment } & Treatment & \multicolumn{3}{c|}{ Cumulative developmental time (dah) } \\
& & Z3 & Z4 & FI \\
\hline Z2-postmoult (2 dah) & Control & $4.2 \pm 0.16$ & $7.3 \pm 0.15^{\mathrm{a}}$ & $10.6 \pm 0.14^{\mathrm{a}}$ \\
& Darkness & $4.9 \pm 0.07$ & $8.5 \pm 0.20^{\mathrm{b}}$ & $12.8 \pm 0.26^{\mathrm{b}}$ \\
& Dorsal spine ablation & $4.9 \pm 0.06$ & $8.0 \pm 0.06^{\mathrm{ab}}$ & $11.4 \pm 0.23^{\mathrm{ab}}$ \\
& Eyestalk ablation & $4.8 \pm 0.26$ & $7.5 \pm 0.25^{\mathrm{ab}}$ & $10.5 \pm 0.60^{\mathrm{a}}$ \\
Z2-premoult (3 dah) & Eyestalk ablation & $4.2 \pm 0.12$ & $7.1 \pm 0.13$ & $9.9 \pm 0.48$ \\
Z3-postmoult (4 dah) & Control & & $6.9 \pm 0.06$ & $10.2 \pm 0.10$ \\
& Darkness & & $7.0 \pm 0.03$ & $11.1 \pm 0.10$ \\
& Dorsal spine ablation & & $7.0 \pm 0.04$ & $10.2 \pm 0.08$ \\
& Eyestalk ablation & & $7.0 \pm 0.05$ & $9.6 \pm 0.12$ \\
Z3-premoult (5 dah) & Eyestalk ablation & & $6.0 \pm 0.00$ & $9.3 \pm 0.14$ \\
Z4-postmoult (6 dah) & Control & & & $9.8 \pm 0.15$ \\
& Darkness & & & $9.9 \pm 0.10$ \\
& Dorsal spine ablation & & & $9.9 \pm 0.05$ \\
& Eyestalk ablation & & & $9.5 \pm 0.33$ \\
Z4-intermoult (7 dah) & Eyestalk ablation & & $9.7 \pm 0.14$ \\
Z4-premoult (8 dah) & Eyestalk ablation & & $9.0 \pm 0.06$ \\
& & & & \\
\hline
\end{tabular}

individuals from the darkness and eyestalk ablation treatment groups relative to the other treatment groups (Fig. 3a). The CHL, CHLr, PL and PLr values were lower in eyestalk-ablated larvae than in the other treatment groups (Fig. 3b,c,f,g). The larval age (Z2- and Z3-postmoult) when treatments were conducted did not significantly affect the CL $(F=3.862$, df $=1,27, \mathrm{p}=$ 0.060), but did have a significant effect on CHL, CHLr, PL and PLr (CHL, $F=5.987, \mathrm{df}=$ $1,27, \mathrm{p}=0.0212 ; \mathrm{CHLr}, F=$ 5.433, df $=1,27, \mathrm{p}=0.0275$; PL, $F=9.686$, df $=1,27, \mathrm{p}=$ $0.0044 ;$ PLr, $F=9.382$, df $=1$, 27, $\mathrm{p}<0.0001)$. The differences between larval ages were minor within the control, darkness, and dorsal spine ablation groups (Fig. 3a-c,f,g). However, CL, CHL, PL, CHLr stage, $\chi^{2}=5.736, \mathrm{df}=3, \mathrm{p}=0.1252$ ). The time needed to reach the fifth-instar stage ranged from 9.6 to 11.1 dah. When treatments were performed during the Z4-postmoult, they had no significant effect on the developmental time required to reach the fifthinstar stage $\left(\chi^{2}=0.9132\right.$, df $\left.=3, p=0.8222\right)$, which ranged from 9.5 to 9.9 dah. The developmental time needed to reach the fifth-instar stage in the eyestalk ablation groups treated at Z2-, Z3- and Z4-premoult, and Z4-intermoult were $9.9 \pm 0.48,9.3 \pm 0.149 .0 \pm 0.06$ and $9.7 \pm 0.14$ dah, respectively. Thus, eyestalk ablation did not affect the larval developmental velocity.

\section{Morphology of Z4 larvae}

The mean values of measurements in each group are summarised in Tables S1 \& S2 in the Supplement at www.int-res.com/articles/suppl/s001p057_supp.pdf, and the comparisons between treatments or larval ages at treatments are shown in Figs. $3 \& 4$. The treatments significantly affected the CL, CHL, CHLr, PL and PLr values of Z4 larvae (CL, $F=10.42, \mathrm{df}=3$, $27, \mathrm{p}=0.0001$; CHL, $F=26.68, \mathrm{df}=3,27, \mathrm{p}<0.0001$; CHLr, $F=29.04, \mathrm{df}=3,27, \mathrm{p}<0.0001$; PL, $F=22.73$, $\mathrm{df}=3,27, \mathrm{p}<0.0001 ;$ PLr, $F=23.96, \mathrm{df}=3,27, \mathrm{p}<$ 0.0001). The CL values were significantly smaller in and PLr increased significantly as the age at eyestalk ablation increased (Fig. 3a-c,f,g) (see statistical values in Fig. $4 \mathrm{a}-\mathrm{C}, \mathrm{f}, \mathrm{g})$. The treatments also significantly affected the DSL and DSLr values (DSL, $F=132.65$, $\mathrm{df}=3,27, \mathrm{p}<0.0001 ;$ DSLr, $F=136.30, \mathrm{df}=3,27, \mathrm{p}<$ 0.0001 ), which were lowest in the dorsal spine ablation group and highest in the eyestalk ablation group (Fig. 3d,h). The larval age at which treatments were conducted had no effect on the DSL and DSLr (DSL, $F=0.9332, \mathrm{df}=1,27, \mathrm{p}=0.3426 ; \mathrm{DSLr}, F=2.219, \mathrm{df}=$ $1,27, p=0.1480$ ) (Fig. 3d,h). Similarly, the timing of eyestalk ablation had no effect on DSL and DSLr (Fig. 4d,h). The treatments had a significant effect on FLr but not FL (FL, $F=0.7048$, df $=3,27, \mathrm{p}=0.5575$; FLr, $F=0.4 .587$, df $=3,27, \mathrm{p}=0.0101)$. The dorsal spine ablated larvae had smaller FLr values than larvae from other treatment groups (Fig. 3e,i). The larval age at treatment had a significant effect on the FL and FLr values (FL, $F=7.178$, df $=1,27, \mathrm{p}=0.0124$; FLr, $F=6.367$, df $=1,27, \mathrm{p}=0.0178)$ : the larvae treated at Z3-postmoult had slightly higher FL scores but lower FLr values than the larvae treated at Z2postmoult (Fig. 3e,i). The timing of eyestalk ablation did not significantly affect the FL (Fig. 4e), whereas a delay in eyestalk ablation was associated with a slight but significant decrease in FLr (Fig. 4i). Thus, there were distinct differences in the effects of eye- 

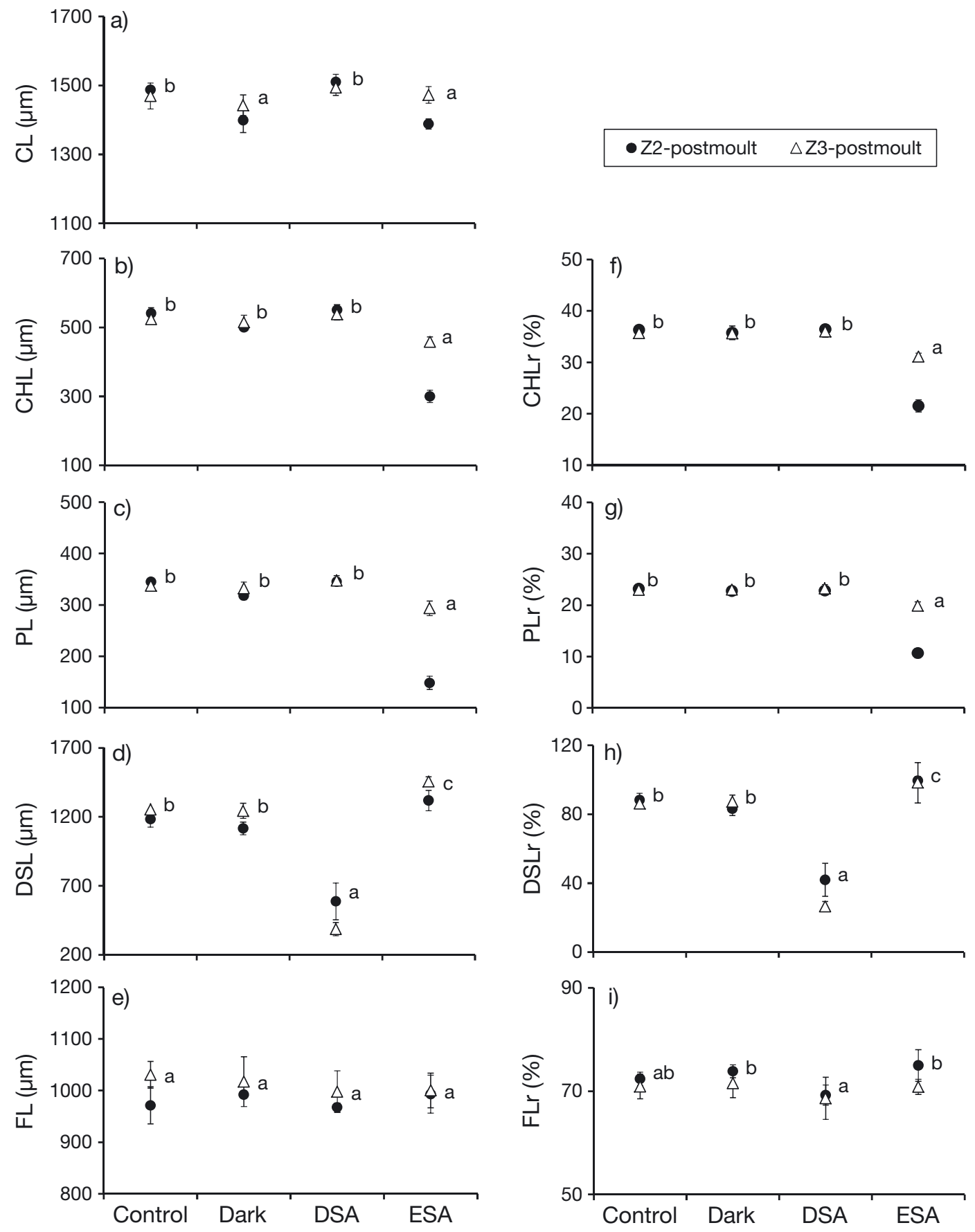

Fig. 3. Differences in (a) carapace length (CL), (b) chela length (CHL), (c) pleopod length (PL), (d) dorsal spine length (DSL), (e) telson furcae length (FL), (f) relative chela length (CHLr), (g) relative pleopod length (PLr), (h) relative dorsal spine length (DSLr), and (i) relative telson furcae length (FLr) in fourth stage zoeae of Portunus trituberculatus between the control (Control), darkness (Dark), dorsal spine ablation (DSA) and eyestalk ablation (ESA) treatment groups. Vertical bars indicate the SD of the 4 replicates in each treatment gorup. Significant differences among treatments are indicated by a different letter $(p<0.05)$

stalk ablation on the morphological character traits of Z4 larvae. The morphogenesis of chelae and pleopods, which become enlarged towards MG, was consistently suppressed by eyestalk ablation, and this effect became more prominent when ablation was performed earlier. Conversely, eyestalk ablation had little effect on the dorsal spine and telson furcae, which disappear during metamorphosis into MG. 

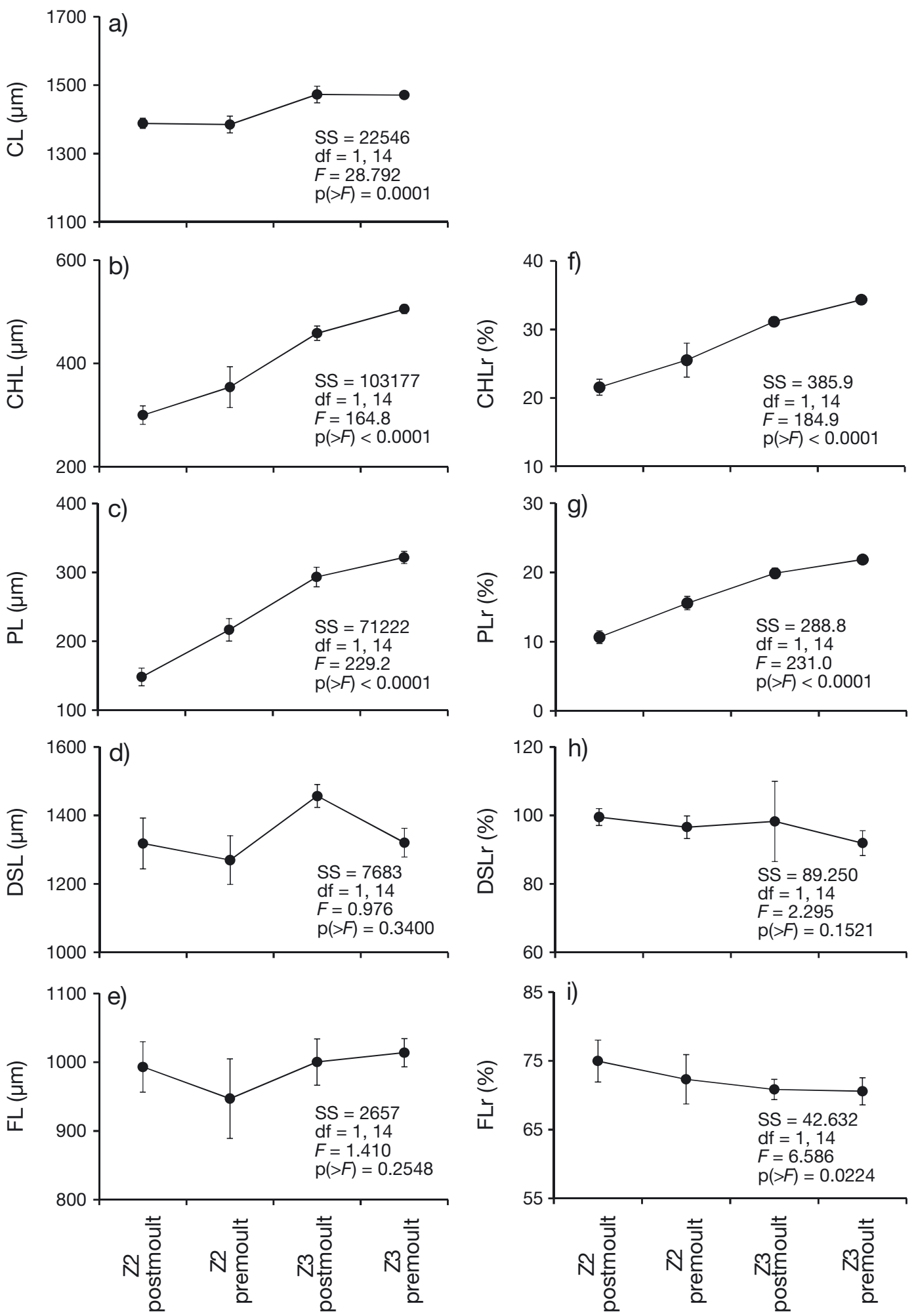

Fig. 4. Changes in (a) carapace length (CL), (b) chela length (CHL), (c) pleopod length (PL), (d) dorsal spine length (DSL), (e) telson furcae length (FL), (f) relative chela length (CHLr), (g) relative pleopod length (PLr), (h) relative dorsal spine length (DSLr), and (i) relative telson furcae length (FLr) of fourth stage zoeae of Portunus trituberculatus following eyestalk ablation at various times. Vertical bars indicate the SD of the 4 replicates in each treatment group. The results of analysis of deviance by an F-test (Type II) to evaluate the effects of time of eyestalk ablation are shown for each measurement 


\section{Morphology of fifth-instar larvae}

The mean values of measurements in each group are summarised in Tables S3, S4 \& S5 in the Supplement at www.int-res.com/articles/suppl/s001p057 supp.pdf, and the comparisons between treatments or larval ages at treatments are shown in Figs. 5, 6 \& 7. The treatments significantly affected all the measurements (CL, CHL, CHLr, DSL, FL, DSf, TELf) of fifth-instar larvae (CL, $F=7.659, \mathrm{df}=3,35, \mathrm{p}=$ 0.0005; CHL, $F=29.057, \mathrm{df}=3,43, \mathrm{p}<0.0001$; CHLr, $F=4.556, \mathrm{df}=3,35, \mathrm{p}<0.0001 ; \mathrm{DSL}, F=$ $24.838, \mathrm{df}=3,43, \mathrm{p}<0.0001 ; \mathrm{FL}, F=25.975, \mathrm{df}=3$, $43, \mathrm{p}<0.0001$; DSf, $F=10.417, \mathrm{df}=3,43, \mathrm{p}<$ 0.0001; TELf, $F=15.371, \mathrm{df}=3,43, \mathrm{p}<0.0001)$. The CL was lower in the darkness treatment group than in the other treatments (Fig. 5a). The eyestalk ablated larvae had higher DSL, FL, DSf and TELf

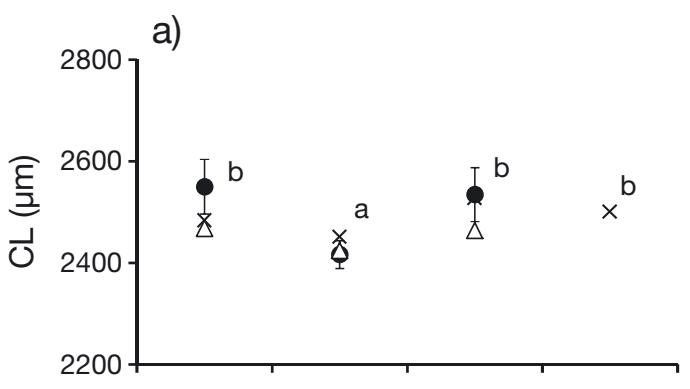

b)

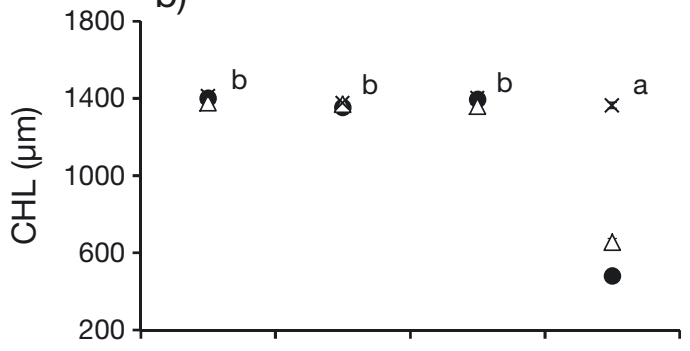

c)

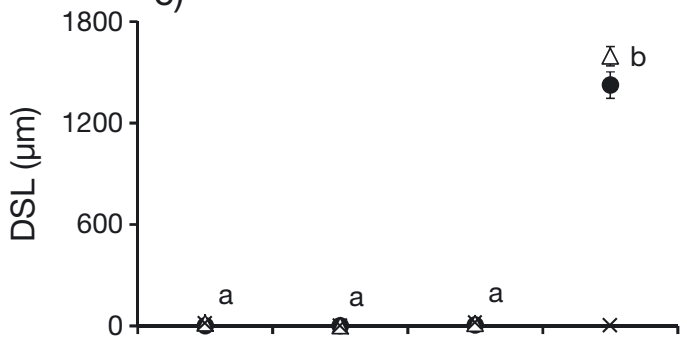

d)

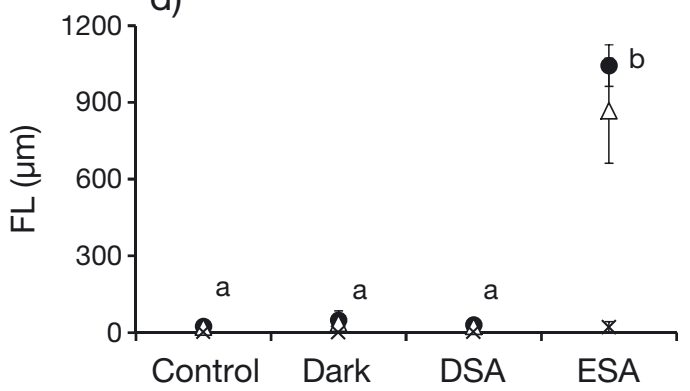

- Z2-postmoult $\triangle$ Z3-postmoult $\times$ Z4-postmoult

■Z2-postmoult $\boxminus$ Z3-postmoult $\square$ Z4-postmoult e)
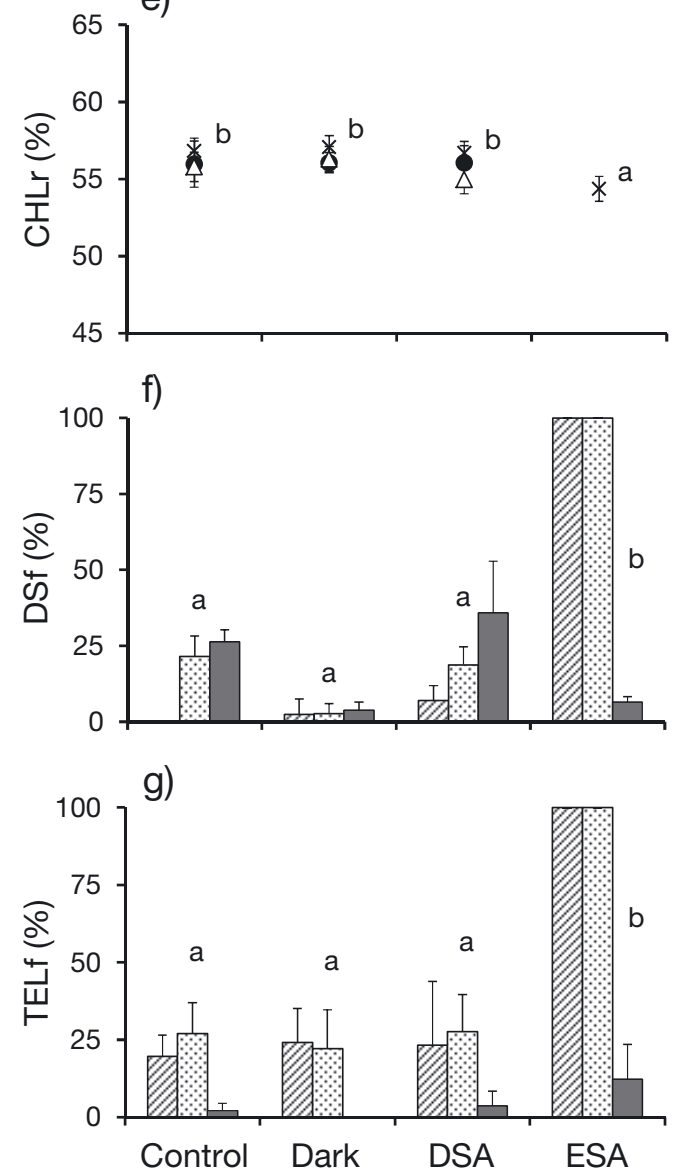

Fig. 5. Differences in (a) carapace length (CL), (b) chela length (CHL), (c) dorsal spine length (DSL), (d) telson furcae length (FL), (e) relative chela length (CHLr), (f) frequency of retained dorsal spine (DSf) and (g) frequency of retained furcae on the telson (TELf) of fifth-instar Portunus trituberculatus larvae between the control (Control), darkness (Dark), dorsal spine ablation (DSA) and eyestalk ablation (ESA) treatment groups. Vertical bars indicate the SD of the 4 replicates in each treatment group. Significant differences among treatments are indicated by a different letter $(p<0.05)$ 

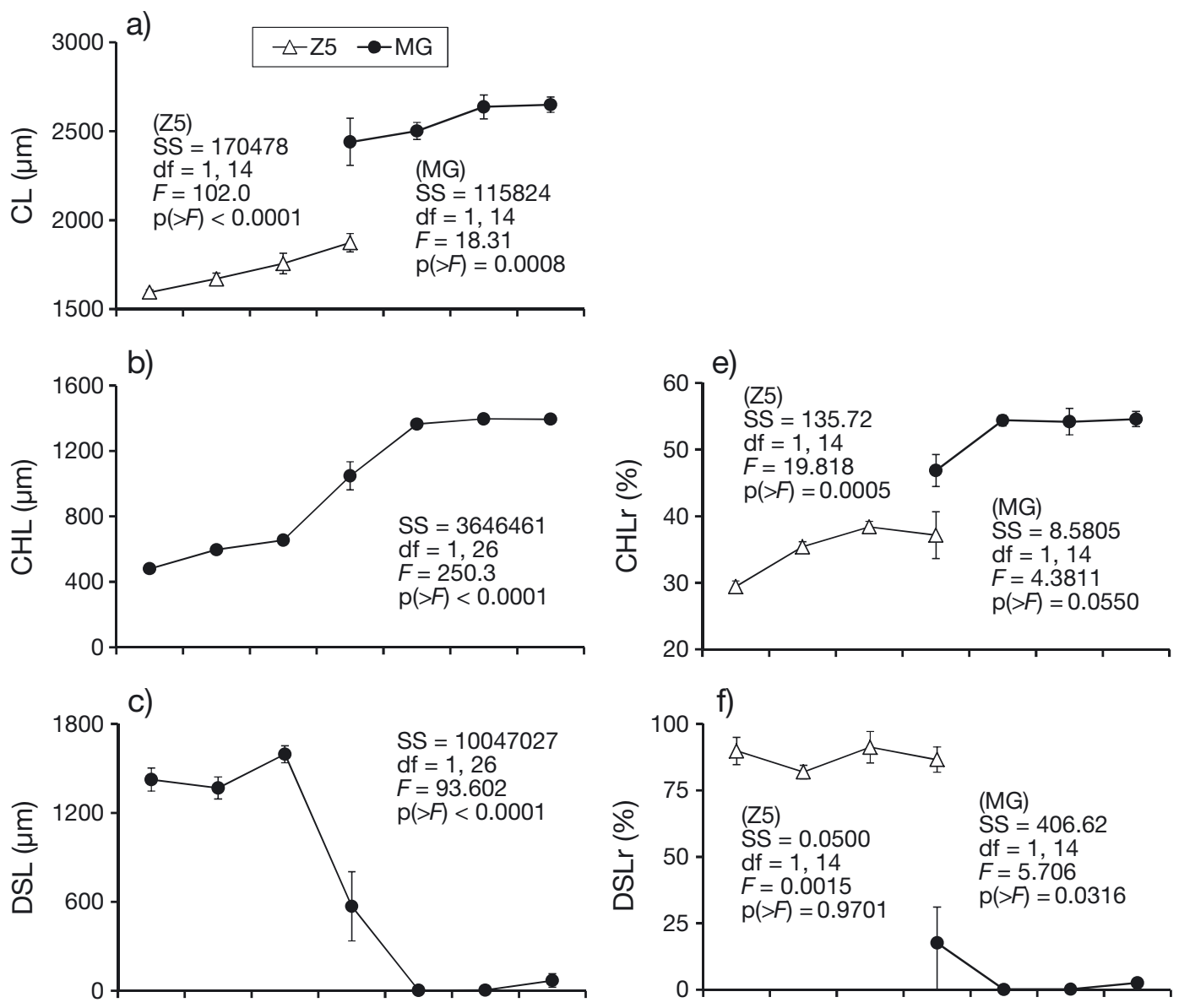

d)
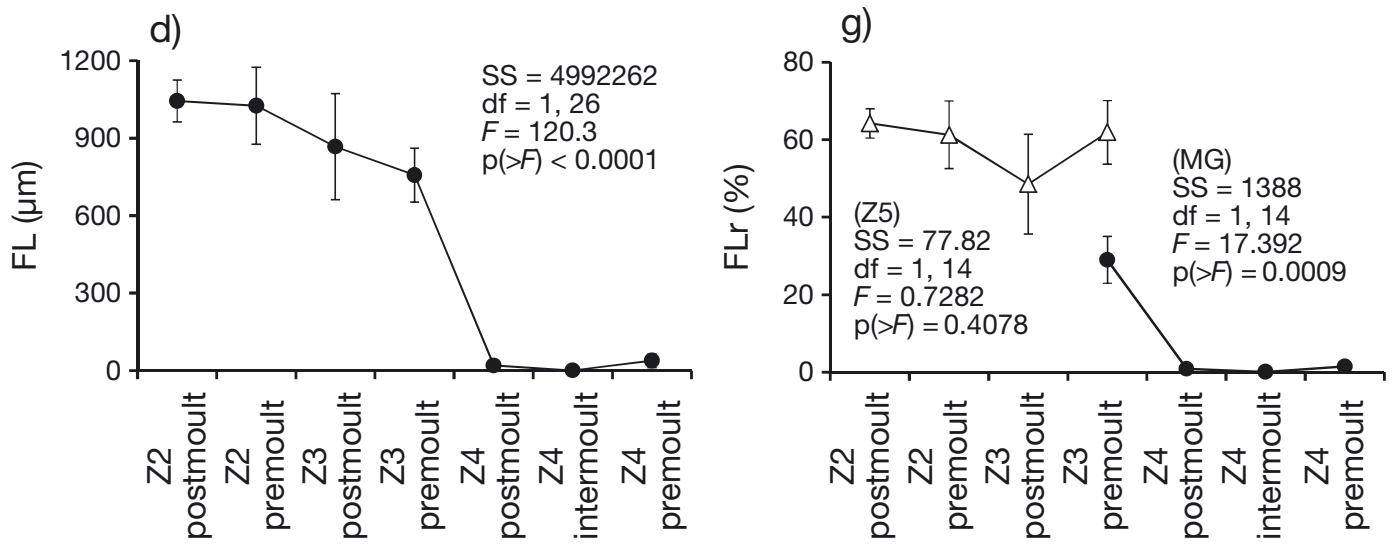

Fig. 6. Changes in (a) carapace length (CL), (b) chela length (CHL), (c) dorsal spine length (DSL), (d) telson furcae length (FL), (e) relative chela length (CHLr), (f) relative dorsal spine length (DSLr), and (g) relative telson furcae length (FLr) of fifth-instar Portunus trituberculatus larvae following eyestalk ablation at various times. Vertical bars indicate the SD of the 4 replicates in each treatment group. The results of an analysis of deviance by an F-test (Type II) to evaluate the effects of timing of eyestalk ablation are shown for each measurement. Because the method of measuring carapace length differed between fifth stage zoeae (Z5) and megalopae (MG) (see Fig. 1), the data for CL, CHLr, PLr, DSLr and FLr for Z5 and MG were analysed separately

values and lower CHL and CHLr values than the other treatment groups, particularly when ablation was conducted during the postmoult of $\mathrm{Z} 2$ and $\mathrm{Z} 3$ (Fig. 5b-g). The effects of larval age at treatment on the CHL, CHLr, DSL, FL and TELf were significant (CHL, $F=13.77, \mathrm{df}=1,43, \mathrm{p}=0.0006 ;$ CHLr, $F=$ 5.453, $\mathrm{df}=1,35, \mathrm{p}=0.0254 ; \mathrm{DSL}, F=8.009, \mathrm{df}=1$, $43, \mathrm{p}=0.0070 ; \mathrm{FL}, F=14.03, \mathrm{df}=1,43, \mathrm{p}=0.0005$; 


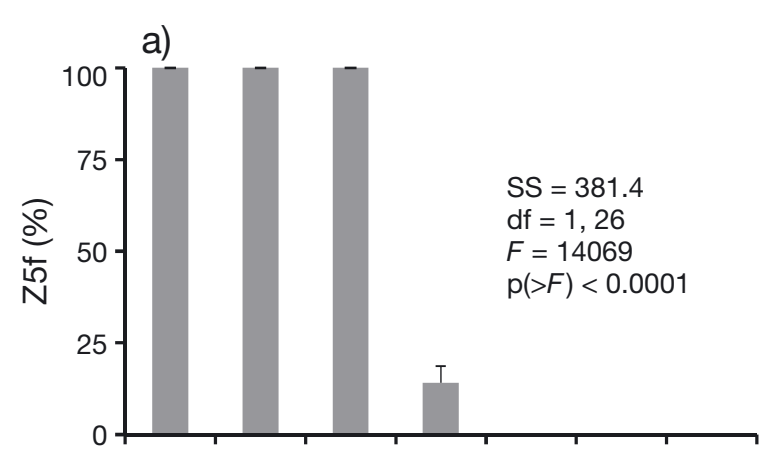

b)
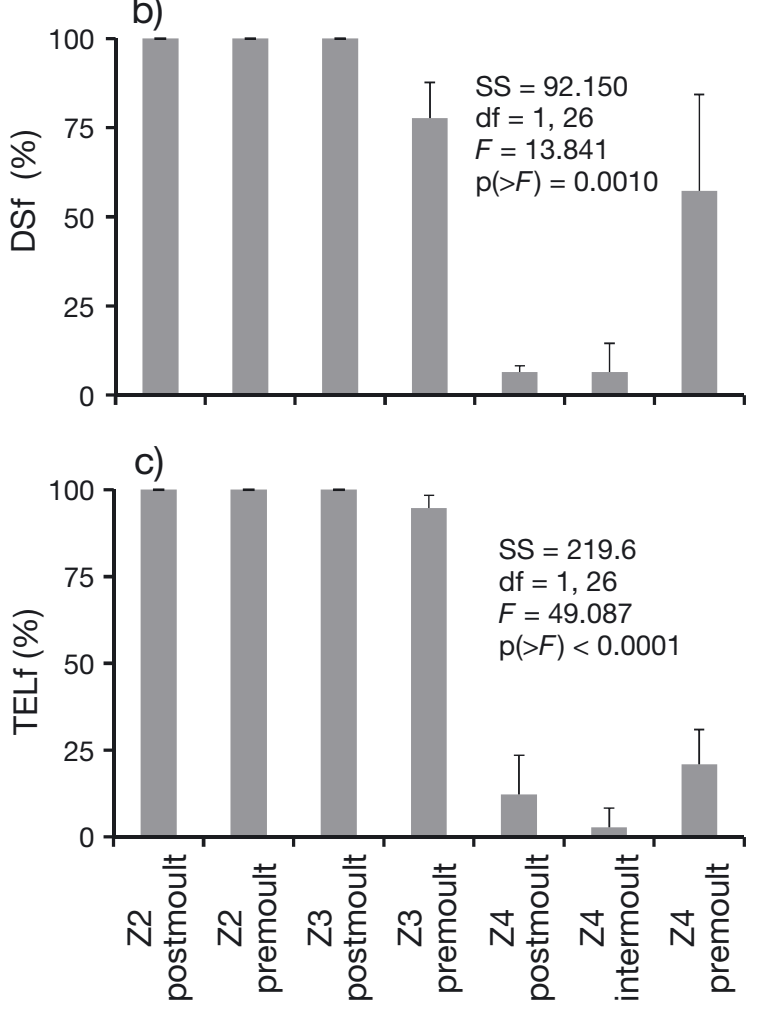

Fig. 7. Changes in the frequency of occurrence of (a) supernumerary fifth stage zoea (Z5f), (b) retained dorsal spine (DSf), and (c) retained furcae on the telson (TELf) in fifth-instar Portunus trituberculatus larvae following eyestalk ablation at various times. Vertical bars indicate the SD of the 4 replicates in each treatment group. The results of an analysis of deviance by an F-test (Type II) to evaluate the effects of timing of eyestalk ablation on the measurements are shown for each morphological trait

TELf, $F=43.37, \mathrm{df}=1,43, \mathrm{p}<0.0001)$, but the differences between larval ages (Z2-, Z3- and Z4-postmoult) were small in the control, darkness and dorsal spine ablation groups compared with the eyestalk ablation group (Fig. 5b-g). Larval age at which treatments were conducted had no effect on CL and DSf $(C L, F=0.4696, \mathrm{df}=1,35, \mathrm{p}=0.4977 ; \mathrm{DSf}, F=$ $0.7006, \mathrm{df}=1,43, \mathrm{p}=0.4072$ ).
All larvae in the eyestalk ablation treatment group moulted to Z5 when the eyestalks were ablated prior to the postmoult of Z3 (Figs. 1d, 6a \& 7a). In a preliminary rearing experiment using eyestalk-ablated zoeae, we confirmed that these Z5 larvae moulted to the next instar stage and had zoeal morphology (sixth stage zoeae, Z6) (Fig. 1e). In Z5 larvae produced by eyestalk ablation before the Z3-premoult, the CL and CHLr tended to be larger as ablation was delayed, and DSLr and FLr were not significantly affected by the timing of ablation (Fig. 6a,e-g). The effects of eyestalk ablation on Z5 larvae were consistent with those observed in Z4 larvae. When the eyestalks were ablated at the premoult of $Z 3$, the frequency of MG was higher than that of Z5 (Fig. 7a), but these MG had zoeal morphological features (as shown in Fig. 1c), such as small chela, a dorsal spine and telson furcae (Fig. 6e-g). Conversely, all larvae successfully moulted into MG when the eyestalks were ablated after the postmoult of Z4 (Fig. 7a), and few zoeal features were retained in these MG (Fig. 6b-g). The effects of timing of ablation on CHL, DSL, FL, DSf and TELf were all statistically significant (Figs. 6b-d $\& 7 \mathrm{~b}, \mathrm{c})$. Our data suggest that metamorphosis to $\mathrm{MG}$ accompanying the resorption of a dorsal spine and telson furcae was inhibited by eyestalk ablation before the postmoult of Z3, and eyestalk ablation in the premoult of Z3 induced immature morphology in the MG.

\section{DISCUSSION AND CONCLUSIONS}

Eyestalk ablation reduced larval survival in Portunus trituberculatus. Because a number of hormones that play important physiological roles are secreted from eyestalks (e.g. crustacean hyperglycaemic hormone, moult-inhibiting hormone, mandibular organinhibiting hormone and vitellogenesis-inhibiting hormone) (Keller 1992, Liu \& Laufer 1996, Hopkins 2012), the absence of the eyestalk is expected to result in physiological abnormalities and lowered survival. However, in the present study, at least $42 \%$ of eyestalk-ablated larvae survived to the fifth-instar stage, suggesting that the absence of eyestalks is not lethal for crab larvae. In Rhithropanopeus harrisii, Homarus americanus and Alpheus heterochaelis, the carapace length of MG or postlarva was increased by eyestalk ablation at an early zoeal stage (Costlow 1966a, Snyder \& Chang 1986, Gross \& Knowlton 1999). However, in this study, the CL was smaller in ablated $\mathrm{Z} 4$ individuals than in the control group. Because the $\mathrm{CL}$ of $\mathrm{Z} 4$ individuals that were reared in darkness 
was also smaller, the small CL in eyestalk-ablated larvae can be inferred to have been caused by their loss of vision. Andrés et al. (2010) demonstrated that constant darkness reduced the somatic growth of Portunus pelagicus larvae, by decreasing the number of prey encounters due to the low swimming activity of larvae in the dark. Thus, the reduction in food intake attributed to the loss of vision (darkness condition) may have affected the somatic growth of ablated larvae. Unfavourable dietary conditions result in the occurrence of the additional supernumerary zoeal stage (Minagawa \& Murano 1993, Zeng et al. 2004). However, the occurrence of supernumerary Z5 following early eyestalk ablation in the present study is not thought to be caused by lower food intake due to their loss of vision, because the larvae that were reared in the dark were able to moult into normal megalopae despite the small CL during the Z4 and MG stages. The duration of larval development was also not different between ablated and control larvae. Thus, the effects of eyestalk ablation on larval morphogenesis could be evaluated without being confounded by retardation or acceleration of growth.

Our study is the first to demonstrate the effects of eyestalk ablation on zoeal morphogenesis in decapod crustacean larvae. Our results clearly showed that the morphogenesis of chelae and pleopods of Z4 larvae was suppressed by eyestalk ablation, and the effect was stronger when the treatment was applied earlier in development. The chelae and pleopods become enlarged as the larvae metamorphose into MG, suggesting that zoeal morphogenesis toward the megalopal stage is also regulated by the endocrine cells located in the eyestalks. Based on the timing of effects we observed, the signal from the eyestalks accelerates zoeal morphogenesis from early on in the zoeal stages, beginning no later than the postmoult of Z2. Though the larvae of $P$. trituberculatus normally start to develop rudimentary chelae and pleopods at the Z3 stage, the regulation of this morphogenesis begins prior to this, early in zoeal development. Furthermore, we observed a linear increase in CHLr and PLr as the timing of ablation was delayed, suggesting that the eyestalk neurosecretory system exerts continuous control throughout zoeal development. In contrast, eyestalk ablation had little effect on the dorsal spine or furcae on the telson of Z4 larvae, both of which disappear during metamorphosis into MG. This suggests that the resorption of these body parts is not under continuous regulation by the eyestalk neurosecretory system.

We observed a transition in the effects of eyestalk ablation on the morphology of the fifth-instar larvae related to the time of ablation. Ablation prior to the premoult of Z3 clearly inhibited metamorphosis into MG. Ablation at this point (Z3-premoult) resulted in an intermediate morphology between zoeae and MG, with individuals retaining a small dorsal spine and furcae on the telson but having a megalopalshaped carapace. These observations strongly suggest that the premoult of $\mathrm{Z} 3$ is a critical point with respect to the control of metamorphosis by the endocrine system in eyestalks. Costlow (1966a) demonstrated that metamorphosis into MG was inhibited when the eyestalk was ablated prior to the end of Z3 in $R$. harrisii, a species that normally terminates the zoeal stage at Z4. Similarly, eyestalk ablation prior to Z2 inhibited metamorphosis and resulted in the occurrence of a supernumerary Z4 in Sesarma reticulatum, a species that normally terminates the zoeal stage at Z3 (Costlow 1966b). The critical time for $A$. heterochaelis and $H$. americanus, species that normally have 3 larval (zoeal) stages, was during the premoult of the second larval stage (Charmantier \& Aiken 1987, Charmantier et al. 1988, Knowlton 1994, Gross \& Knowlton 2002). Thus, it appears to be a common occurrence among decapod crustacean species that the metamorphosis into postlarva is inhibited when the eyestalks are ablated before the premoult during the penultimate zoeal stage. The occurrence of larvae with morphology intermediate between zoeae and MG as a result of eyestalk ablation at this critical point can be interpreted as the outcome of incomplete metamorphosis owing to the lack of endocrine control by the neurosecretory system located in the eyestalks. Taken further, this suggests that an endocrine signal is secreted from the eyestalks at precisely this time. The larvae were able to complete the metamorphosis into MG when the eyestalks were ablated immediately after the moult to Z4. Thus, the morphogenesis accompanying resorption of the dorsal spine and telson furcae appears to have already been initiated prior to the beginning of the last zoeal stage (Z4). Given this, the regulation of metamorphosis involving resorption by the eyestalk neurosecretory system appears to be instantaneous, likely controlled by a short-term surge in hormone/s.

We demonstrated that the neurosecretory system in the eyestalks most likely regulates larval morphogenesis in 2 ways. The morphogenesis of the chelae and pleopods is controlled continuously throughout the zoeal stages, whereas resorption of the dorsal spine and telson furcae is controlled instantaneously at a critical point during the premoult of Z3. An important factor in understanding this regulatory system is that the former is characterised by enlargement and the latter by resorption. Because the 
enlargement of body parts and appendages requires a large amount of energy, it may be advantageous to spread the energy demand over a longer period. In this sense, it is reasonable that larvae would enlarge their chelae and pleopods as much as possible when nutritional conditions allow during the zoeal stage, before metamorphosis, even though the chelae and pleopods are not functional during the zoeal stages. This strategy likely reduces the energy burden during metamorphosis and raises the success rate of metamorphosis. Conversely, the dorsal spine and telson furcae play important roles in preventing predation and facilitating swimming during zoeal stages (Morgan 1989), but their resorption does not place energy demands on the individual. The larvae require these body parts during the zoeal stages, but they must then be quickly resorbed during metamorphosis. The 2 pathways by which the eyestalk neurosecretory system regulated morphogenesis in our study fit well with these complex requirements.

n-3 highly unsaturated fatty acids (n-3 HUFA) are essential fatty acids for larvae of Scylla serrata and $P$. trituberculatus (Hamasaki et al. 1998, Takeuchi et al. 1999a,b, Suprayudi et al. 2002, 2004). Zoeal morphogenesis of the chelae and pleopods in S. serrata and $P$. trituberculatus can be accelerated by altering the dietary intake of n-3 HUFA, such as docosahexaenoic acid and eicosapentaenoic acid which are contained in rotifers (Hamasaki et al. 2002b, Arai et al. 2007, Dan \& Hamasaki 2011). Zoeal morphogenesis is also affected by the salinity of the rearing water; the CHLr of the last zoeae of S. serrata was high when held at the optimal salinity but low at lower salinities (Dan \& Hamasaki 2011). Thus, when zoeae experience good nutritional and environmental conditions (e.g. n-3 HUFA and salinity), they can divert more energy into the morphogenesis of chelae and pleopods. In other words, the eyestalk neurosecretory system controls the partitioning of energy between somatic growth and morphogenesis towards MG, depending on the nutritional and environmental conditions. Interestingly, when larvae are supplied with high levels of n-3 HUFA under optimal rearing conditions during seed production, the chelae and pleopods become excessively enlarged, which results in mass mortality because of incomplete moulting into MG. The old exuviae can not be shed because of the size of the chelae and walking legs, a phenomenon that is termed 'moult-death syndrome' (Mann et al. 1999, Hamasaki et al. 2002a, Arai et al. 2004, Takano et al. 2004, Dan \& Hamasaki 2011, Silva et al. 2012). Thus, the cause of moult-death syndrome may relate to the regulation of morphogenesis by the eyestalk neurosecretory system as a normal response to the rearing condition. To prevent moult-death syndrome, culturists should control dietary intake such that energy inputs remain below a certain threshold, to prevent excess growth (Hamasaki et al. 2002b).

We concluded that the abnormal morphology of MG (i.e. retention of immature zoeal traits) during seed production of $P$. trituberculatus was the major cause of mass mortality (Dan et al. 2013). This is consistent with our current observation of immature morphology of $P$. trituberculatus MG following eyestalk ablation during the premoult of Z3; MG retained both a small dorsal spine and furcae on the telson. The resorption of these parts is thought to be instantaneously regulated by the eyestalk neurosecretory system during the premoult of Z3. Therefore, we speculate that the abnormalities occurring during seed production are related to disruption of the regulatory system in the eyestalks at this critical period. Recently, we found that the supplementation of phytoplankton such as Chlorella vulgaris and Nannochloropsis sp. into larval rearing water to provide food for rotifers was associated with increases in abnormal morphology of $P$. trituberculatus $\mathrm{MG}$, specifically during the premoult of Z3 (S. Dan et al. unpubl. data), which provides further support for the critical period hypothesis.

The role of the eyestalk neurosecretory system in morphogenesis during metamorphosis has been documented based on changes in phenotype. However, the endocrine system controlling this phenomenon is poorly understood. In adult crustaceans, the moulting cycle is regulated by the secretion of moult-inhibiting hormone from the X-organ-sinus gland complex in the eyestalks and by ecdysteroid, which is produced in the Y-organ and regulated in turn by moultinhibiting hormone (Keller 1992, Nakatsuji et al. 2009, Hopkins 2012). In addition to moult-inhibiting hormone and ecdysteroid, it is thought that the secretion of juvenile hormone (methyl farnesoate) from the mandibular organ and mandibular organ-inhibiting hormone from the X-organ-sinus gland complex play a role in regulating larval metamorphosis (Freeman \& Costlow 1984, Abdu et al. 1998a, Anger 2001b, Gross \& Knowlton 2002). A number of studies have evaluated the effects of these hormones on metamorphosis by injection into the larval body or administration into larval rearing water and tissue culture medium (Freeman \& Costlow 1983, 1984, Snyder \& Chang 1986, Charmantier et al. 1988, Abdu et al. 1998a,b). However, the mechanisms by which these hormones exert their effects remain poorly understood. To document the actions of these hormones in larvae, there is a need for a highly sensitive analysis 
(e.g. gene expression analysis using PCR) linked to quantified morphological traits. We suggest that a species such as $P$. trituberculatus that exhibits significant morphological change during metamorphosis, having both enlarged and resorbed traits, may be suitable for further study.

Acknowledgements. We thank the staff of the Tamano Laboratory of the National Research Institute of Fisheries and Environment of Inland Sea, Fisheries Research Agency for supporting our laboratory work. We are grateful to the the editors and anonymous reviewers for their valuable comments and suggestions, which have improved the manuscript substantially.

\section{LITERATURE CITED}

Abdu U, Takac P, Laufer H, Sagi A (1998a) Effect of methyl farnesoate on late larval development and metamorphosis in the prawn Macrobrachium rosenbergii (Decapoda, Palaemonidae): a juvenoid-like effect? Biol Bull 195: 112-119

Abdu U, Takac P, Yehezkel G, Chayoth R, Sagi A (1998b) Administration of methyl farnesoate through the Artemia vector, and its effect on Macrobrachium rosenbergii larvae. Isr J Aquac Bamidgeh 50:73-81

Andrés M, Rotllant G, Zeng C (2010) Survival, development and growth of larvae of the blue swimmer crab, Portunus pelagicus, cultured under different photoperiod conditions. Aquaculture 300:218-222

Anger K (2001a) Morphology. In: Vonk R (ed) The biology of decapod crustacean larvae. Crustacean issues, Vol 14. A.A. Balkema, Lisse, p 13-40

Anger K (2001b) The molting cycle. In: Vonk R (ed) The biology of decapod crustacean larvae. Crustacean issues, Vol 14. A. A. Balkema, Lisse, p 81-107

Arai D, Hamasaki K, Maruyama K, Obata Y, Tsumura S, Takano M (2004) Relationship between mass mortality of megalops and morphogenesis of zoeas in the seed production of swimming crab Portunus trituberculatus (Brachyura: Portunidae). Bull Jpn Soc Sci Fish 70:567-572 (in Japanese with English Abstract)

Arai D, Takeuchi T, Sugita D, Hamasaki K, Maruyama K (2007) Effect of n-3 HUFA-Chlorella supplied to rearing tank on morphogenesis of swimming crab zoeas of the Portunus trituberculatus (Brachyura: Portunidae). Aquac Sci 55:133-134 (in Japanese with English Abstract)

- Atkins D (1955) The post-embryonic development of British Pinnotheres (Crustacea). Proc Zool Soc Lond 124:687-715

> Castine S, Southgate PC, Zeng C (2008) Evaluation of four dietary protein sources for use in microbound diets fed to megalopae of the blue swimmer crab, Portunus pelagicus. Aquaculture 281:95-99

Charmantier G, Aiken DE (1987) Intermediate larval and postlarval stage of Homarus americanus H. Milne Edwards, 1837 (Crustacea: Decapoda). J Crustac Biol 7: 525-535

> Charmantier G, Charmantier-Daures M, Aiken DE (1988) Larval development and metamorphosis of the American lobster Homarus americanus (Crustacea, Decapoda): Effect of eyestalk ablation and juvenile hormone injection. Gen Comp Endocrinol 70:319-333
Cheng Y, Xugan W, Xiaozhen Y, Hines AH (2008) Current trends in hatchery techniques and stock enhancement for Chinese mitten crab, Eriocheir japonica sinensis. Rev Fish Sci 16:377-384

> Costlow JD (1966a) The effect of eyestalk ablation on larval development of the mud crab, Rhithropanopeus harrisii (Gould). Gen Comp Endocrinol 7:255-274

Costlow JD (1966b) The effect of eyestalk ablation on larval development of the crab, Sesarma Reticulatum Say. In: Barnes H (ed) Some contemporary studies in marine science. George Allen and Unwin, London, p 209-224

> Dan S, Hamasaki K (2011) Effects of salinity and dietary n-3 highly unsaturated fatty acids on the survival, development, and morphogenesis of the larvae of laboratoryreared mud crab Scylla serrata (Decapoda, Portunidae). Aquacult Int 19:323-338

> Dan S, Kaneko T, Takeshima S, Ashidate M, Hamasaki K (2013) Variations in larval morphology and its relationships to survival during mass seed production by swimming crab, Portunus trituberculatus (Brachyura, Portunidae). Aquaculture 414-415:109-118

> Davis JA, Wille M, Hecht T, Sorgeloos P (2005) Optimal first feed organism for south African mud crab Scylla serrata (Forskål) larvae. Aquacult Int 13:187-201

Everitt BS, Hothorn T (2009) A handbook of statistical analyses using R. CRC Press, New York, NY

Fox J, Weisberg S (2011) An R companion to applied regression, 2nd edn. Sage Publications, Thousand Oaks, CA

- Freeman JA, Costlow JD (1980) The molt cycle and its hormonal control in Rhithropanopeus harrisii larvae. Dev Biol 74:479-485

Freeman JA, Costlow JD (1983) Endocrine control of spine epidermis resorption during metamorphosis in crab larvae. Rouxs Arch Dev Biol 192:362-365

Freeman JA, Costlow JD (1984) Endocrine control of apolysis in Rhithropanopeus harrisii larvae. J Crustac Biol 4:1-6

Gore RH (1985) Molting and growth in decapod larvae. In: Wenner AM (ed) Larval growth. Crustacean issues, Vol. 2. A. A. Balkema, Boston, p 1-65

> Gross PS, Knowlton RE (1997) Effects of timed eyestalk ablation on molting in larvae of the snapping shrimp, Alpheus heterochaelis Say. Invertebr Reprod Dev 32:119-126

> Gross PS, Knowlton RE (1999) Variation in size after eyestalk ablation in larvae of the snapping shrimp Alpheus heterochaelis. J Crustac Biol 19:8-13

> Gross PS, Knowlton RE (2002) Morphological variations among larval-postlarval intermediates produced by eyestalk ablation in the snapping shrimp Alpheus heterochaelis Say. Biol Bull 202:43-52

- Hamasaki K, Kitada S (2008) Potential of stock enhancement for decapod crustaceans. Rev Fish Sci 16:164-174

Hamasaki K, Takeuchi T, Sekiya S (1998) Dietary value for larval swimming crab Portunus trituberculatus of marine rotifer Brachionus rotundiformis cultured with several feeds. Bull Jpn Soc Sci Fish 64:841-846 (in Japanese with English Abstract)

Hamasaki K, Suprayudi MA, Takeuchi T (2002a) Mass mortality during metamorphosis to megalops in the seed production of mud crab Scylla serrata (Crustacea, Decapoda, Portunidae). Fish Sci 68:1226-1232

Hamasaki K, Suprayudi MA, Takeuchi T (2002b) Effect of dietary n-3 HUFA on larval morphogenesis and metamorphosis to megalops in the seed production of mud crab, Scylla serrata (Brachyura: Portunidae). Aquac Sci 50:333-340 
Hamasaki K, Fukunaga K, Maruyama K (2003) Egg development and incubation period of the swimming crab Portunus trituberculatus (Decapoda: Portunidae) reared in the laboratory. Crustac Res 32:45-54

Hamasaki K, Obata Y, Dan S, Kitada S (2011) A review of seed production and stock enhancement for commercially important portunid crabs in Japan. Aquacult Int 19: 217-235

Hopkins PM (2012) The eyes have it: a brief history of crustacean neuroendocrinology. Gen Comp Endocrinol 175: 357-366

> Hothorn T, Bentz F, Westfall P (2008) Simultaneous inference in general parametric models. Biom J 50:346-363

Jinbo T, Dan S, Nakaya M, Ashidate M, Hamasaki K (2013) Effects of n-3 highly unsaturated fatty acid content in Artemia on survival and development of laboratoryreared horsehair crab Erimacrus isenbeckii larvae. Fish Sci 79:459-467

Keenan CP, Blackshaw A (1999) Mud crab aquaculture and biology. Proceedings of an international scientific forum held in Darwin, Australia, 21-22 April 1997. ACIAR Proceedings No. 78. ACIAR, Canberra

Keller R (1992) Crustacean neuropeptides: Structures, functions and comparative aspects. Experientia 48:439-448

Knowlton RE (1994) Effects of larval eyestalk ablation on morphogenesis and molting in the snapping shrimp Alpheus heterochaelis Say. J Exp Zool 270:162-174

Kogane T, Dan S, Hamasaki K (2007) Improvement of larval rearing technique for mass seed production of snow crab Chionoecetes opilio. Fish Sci 73:851-861

Konishi K (1981) A description of laboratory-reared larvae of the commensal crab Pinnaxodes nutuensis Sakai (Decapoda, Brachyura) from Hokkaido, Japan. Annotnes Zool Jap 54:213-229

Little G (1969) The larval development of the shrimp, Palaemon macrodactylus Rathbun, reared in the laboratory, and effect of eyestalk ablation on development. Crustaceana 17:69-87

Liu L, Laufer H (1996) Isolation and characterization of sinus gland neuropeptides with both mandibular organ inhibiting and hyperglycemic effects from the spider crab Libinia emarginata. Arch Insect Biochem Physiol 32:375-385

Mann D, Asakawa T, Pizzutto M (1999) Development of a hatchery system for larvae of the mud crab Scylla serrata at the Bribie Island Aquaculture Research Centre. In: Keenan CP, Blackshaw A (eds) Mud crab aquaculture and biology. Proceedings of an international scientific forum held in Darwin, Australia, 21-22 April 1997. ACIAR Proceedings, Vol 78. ACIAR, Canberra, p 153-158

McCullagh P, Nelder JA (1989) Generalized linear models. Chapman \& Hall, New York, NY

Minagawa M, Murano M (1993) Effects of prey density on survival, feeding rate and development of zoeas of the red frog crab Ranina renina (Crustacea, Decapoda, Raninidae). Aquaculture 113:91-100

Morgan SG (1989) Adaptive significance of supination in estuarine crab zoeae. Ecology 70:464-482

Nakatsuji T, Lee CY, Watson D (2009) Crustacean moltinhibiting hormone: structure, function, and cellular mode

Editorial responsibility: Amir Sagi,

Beer Sheva, Israel of action. Comp Biochem Physiol A Mol Integr Physiol 152:139-148

R Development Core Team (2013) R: a language and environment for statistical computing. R Foundation for Statistical Computing, Vienna

Silva UTA, Cottens K, Ventura R, Boeger WA, Ostrensky A (2012) Different pathways in the larval development of the crab Ucides cordatus (Decapoda, Ocypodidae) and their relation with high mortality rates by the end of massive larvicultures. Pesqui Vet Bras 32:284-288

Snyder MJ, Chang ES (1986) Effects of eyestalk ablation on larval molting rates and morphological development of the American lobster, Homarus americanus. Biol Bull 170:232-243

Suprayudi MA, Takeuchi T, Hamasaki K, Hirokawa J (2002) The effect of n-3 HUFA content in rotifers on the development and survival of mud crab Scylla serrata larvae. Aquac Sci 50:205-212

Suprayudi MA, Takeuchi T, Hamasaki K (2004) Essential fatty acids for larval mud crab Scylla serrata: implications of the lack of ability to bioconvert C18 unsaturated fatty acid to highly unsaturated fatty acids. Aquaculture 231: 403-416

Takano M, Arai D, Obata Y, Tsumura S, Ashidate M (2004) Effect of microalgal addition to the mass seed production tank on morphogenesis of the fifth-stage zoea of mud crab Scylla paramamosain. Technical report of the National Center for Stock Enhancement of Japan 2:27-30 (in Japanese) (available at http://ncse.fra.affrc.go.jp//cgi-bin/ download/dcount.cgi/gihou-no2.pdf)

Takeuchi T, Nakamoto Y, Hamasaki K, Sekiya S, Watanabe $\mathrm{T}$ (1999a) Requirement of n-3 highly unsaturated fatty acids for larval swimming crab Portunus trituberculatus. Bull Jpn Soc Sci Fish 65:797-803 (in Japanese with English Abstract)

Takeuchi T, Satoh N, Sekiya S, Shimizu T, Watanabe T (1999b) The effect of dietary EPA and DHA on the moulting rate of larval swimming crab Portunus trituberculatus. Bull Jpn Soc Sci Fish 65:998-1004 (in Japanese with English Abstract)

Wang G, Li S, Zeng C, Lin S, Kong X, Ai C, Lin Q (2005) Status of biological studies and aquaculture development of the mud crab, Scylla serrata, in China: an experimental ecological studies. Aquacult Int 13:459-468

Warner GF (1968) The larval development of the mangrove tree crab, Aratus pisonii (H. Milne Edwards), reared in the laboratory (Brachyura, Grapsidae). Crustaceana (Suppl) 2:249-258

Williamson DI (1965) Some larval stages of three Australian crabs belonging to the families Homolidae and Raninidae, and observation on the affinities of these families (Crustacea: Decapoda). Aust J Mar Freshw Res 16: 369-398

Zeng C, Shaojing L, Zeng H (2004) Occurrence of additional zoea-VI larvae in the mud crab, Scylla paramamosain (Estampador), reared in the laboratory. Hydrobiologia 529:49-58

Zmora O, Findiesen A, Stubblefield J, Frenkel V, Zohar Y (2005) Large-scale juvenile production of the blue crab Callinectes sapidus. Aquaculture 244:129-139

Submitted: February 19, 2014; Accepted: June 19, 2014

Proofs received from author(s): August 8, 2014 